\title{
Short Communication Genetic and epigenetic analyses of MBD3 in colon and lung cancer
}

\author{
Y Zhu', DJ Harrison' and SA Bader*,I \\ 'Sir Alastair Currie Cancer Research UK Laboratories, Division of Pathology, Molecular Medicine Centre, University of Edinburgh, Western General \\ Hospital, Crewe Road, Edinburgh EH4 2XU, UK
}

MBD3 is a member of the methyl-CpG-binding domain family and is located on chromosome 19p/3.3, a region of loss of heterozygosity in colon and lung cancers. We therefore screened samples for abnormalities in MBD3. Our results indicate that MBD3 is not a major target of genetic and epigenetic alteration in these cancers.

British Journal of Cancer (2004) 90,1972-1975. doi:I0.1038/sj.bjc.660 I776 www.bjcancer.com

Published online 13 April 2004

(c) 2004 Cancer Research UK

Keywords: MBD3; colon cancer; lung cancer; mutation; methylation

In humans, the somatic genome is globally methylated, with the exception of $\mathrm{CpG}$ islands. CpG islands are CG-rich regions of DNA, which are coincident with the promoters of $60 \%$ of human housekeeping genes (Antequera and Bird, 1994). DNA methylation is an important epigenetic modification in the human genome, playing an essential role in the control of gene expression. It is well established that DNA methylation is extensively involved in gene imprinting, $\mathrm{X}$ inactivation and development. Aberrant methylation of $\mathrm{CpG}$ islands in the promoter of many cancer-related genes results in silencing of their expression compared with normal cells of the same tissue (Tycko, 2000).

The signal encoded by a particular pattern of DNA methylation is transduced through proteins that bind to methylated CpGs. These proteins contain a specific domain, the methyl-CpG-binding domain (MBD) (Nan et al, 1993). So far, five human MBD proteins have been identified as members of this protein family: MBD1, MBD2, MBD3, MBD4 and MECP2. MBD3 shares about $70 \%$ of overall identity with MBD2 over most of their length (Hendrich and Bird, 1998). MBD3 is a subunit of the NuRD complex that has nucleosome remodelling and histone deacetylase activities (Wade et al, 1998, 1999; Zhang et al, 1999). Although MBD3 does not itself bind directly to methylated DNA, several lines of evidence suggest that MBD3 does play a role as part of the NuRD complex in the maintenance of transcriptionally repressed chromatin. MBD3 is crucial to normal mammalian development as knockout of $\mathrm{Mbd} 3$ in mice is embryonic lethal (Hendrich et al, 2001). Mutations or abnormal expression of $M B D 3$ could therefore play a role in tumorigenesis via inappropriate regulation of other gene expression. Other members (MBD2 and MBD4) of the MBD family have already been associated with colorectal cancer, albeit in different mechanisms. Maintenance of $M B D 2$ expression (normal function being the suppression of transcription from methylated DNA) is required for tumour formation in $A P C^{\mathrm{min}}$ mice (Sansom et al, 2003). Mutation of MBD4 (normal function being the repair of methyl-CpG deamination events) occurs in microsatellite unstable tumours (Bader et al, 1999) and absence of the gene in MBD4 null

*Correspondence: Dr SA Bader; E-mail: s.bader@ed.ac.uk Received 8 July 2003; accepted 19 February 2004; published online 13 April 2004 mice leads to increased genomic mutations and tumour burden in $A P C^{\text {min }}$ mice (Millar et al, 2002).

$M B D 3$ is located on chromosome $19 \mathrm{p} 13.3$, a region reported to suffer $20-50 \%$ loss of heterozygosity $(\mathrm{LOH})$ in sporadic colorectal carcinomas (Dong et al, 1998; Resta et al, 1998; Trojan et al, 2000). According to the data compiled by the Human Genome Mapping Project (available on the website http://www.ncbi.nlm.nih.gov/), $M B D 3$ is within about $500 \mathrm{~kb}$ of the gene LKB1/STK11, which is mutated or abnormally methylated in Peutz-Jeghers syndrome. Peutz-Jeghers patients have hamartomatous polyposis of the gastrointestinal tract and an increased risk of a range of cancers including colon. $L K B 1$ is rarely mutated or methylated (maximum about 20\%), however, in sporadic colorectal carcinomas (Avizienyte et al, 1998; Resta et al, 1998; Esteller et al, 2000; Launonen et al, 2000; Trojan et al, 2000), raising the possibility that another gene in the vicinity is involved in these cancers. The short arm of chromosome 19 is also implicated in up to $86 \%$ of lung cancers (Lukeis et al, 1990; Virmani et al, 1998; Sanchez-Cespedes et al, 2001). In the light of the location of $M B D 3$ in a region of chromosomal loss and its known functions in transcription suppression, it is considered as a candidate tumour-suppressor gene. We therefore performed a mutation screen, expression study and methylation status assay to investigate the possible role of $M B D 3$ in the aetiology of colon and lung cancers.

\section{MATERIAL AND METHODS}

\section{Samples, DNA and RNA extractions}

Cancer cell lines were obtained from the European Collection of Cell Cultures (ECACC)/ATCC, comprising seven colon cancers, 20 lung cancers and one normal lung cell (BW1799) (see Table 1). In all, 51 primary colon tumour samples were part of an unselected, anonymised collection from patients at the Royal Infirmary Edinburgh. DNAs were extracted by standard methods from pellets of cell lines, or from frozen primary tumours. Total RNAs of cell lines were extracted by using Trizol Reagent (Invitrogen) according to the manufacturer's protocol; normal colon tissue RNA was from Stratagene. PolyA + RNA was isolated using a Qiagen direct mRNA kit according to the manufacturer's protocol. 
Table I Cell lines and primers used

\begin{tabular}{|c|c|c|}
\hline Cell lines tissue & Description & Name \\
\hline Primers exon & Primer name and sequence & PCR conditions per pair \\
\hline
\end{tabular}

A measure of $10 \mu \mathrm{g}$ of polyA + RNA was electrophoresed on a $7 \%$ formaldehyde gel and then transferred to Hybond-N (Amersham) nylon membrane by capillary transfer. The membrane was crosslinked by UV light before hybridisation. The northern blot was pre-hybridised for $30 \mathrm{~min}$ at $68^{\circ} \mathrm{C}$ with ExpressHyb solution (Clontech) and hybridised for $1 \mathrm{~h}$ at $68^{\circ} \mathrm{C}$ in the same solution with $50 \mu \mathrm{Ci}^{32} \mathrm{P}$-labelled MBD3 cDNA probe. The cDNA probe was PCR amplified by primer pair MBD3/3, 5'-ACATGCTGGGGGACGTGGA, and MBD3/30, 5'-GCTGCACAGTGGGTGATGTGA, which generated a $587 \mathrm{bp}$ fragment. After appropriate washings, the membrane was exposed to Kodak XAR5 film at $-70^{\circ} \mathrm{C}$ for up to 3 days. Autoradiographic exposure of a low specific activity (so as not to obscure the nearby $2.4 \mathrm{~kb} M B D 3$ band) $\beta$-actin probe was used as a loading control for the lanes.

\section{Examination of MBD3 expression by RT - PCR and Northern blot hybridisation analyses}

Total RNA $(10 \mu \mathrm{g})$ was reverse transcribed with random hexamers using the M-MLV Reverse Transcriptase kit (Invitrogen) according to the manufacturer's instructions. The cDNA $(0.5 \mu \mathrm{l})$ was then amplified in a $20 \mu \mathrm{l}$ reaction under standard conditions. The PCR cycle parameters were as follows: an initial denaturing step at $95^{\circ} \mathrm{C}$ for $5 \mathrm{~min}$, followed by 35 cycles of $\left(30 \mathrm{~s}\right.$ at $95^{\circ} \mathrm{C}, 30 \mathrm{~s}$ at $52^{\circ} \mathrm{C}, 30 \mathrm{~s}$ at $72^{\circ} \mathrm{C}$ ), then $3 \mathrm{~min}$ at $72^{\circ} \mathrm{C}$. The primers used were $\mathrm{MBD} 3 / 1$, $5^{\prime}$-GAAGAAGTTCCGCAGCAA, and MBD3/2a, 5'-GGTCGCTCTTGACCTTGT, which generated a fragment of $260 \mathrm{bp}$. The PCR products were run on $1 \%$ agarose gel in $1 \times \mathrm{TAE}$, and visualised by ethidium bromide staining.

\section{CpG island methylation status analysis}

To examine the methylation status of the MBD3 CpG island, methylation-sensitive/resistant enzymes (HpaII/MspI) were used to digest DNA at CCGG sites, followed by PCR amplification. The presence of the PCR product from HpaII digest indicates that the DNA is protected by methylation from being cut, while no PCR product results if the DNA is not methylated. No PCR product will be obtained from MspI digested DNA because it cuts irrespective of its methylation status. Genomic DNA $(0.5 \mu \mathrm{g})$ from cancer cell lines was digested with $50 \mathrm{U}$ of either HpaII or Msp (NEB) for $16 \mathrm{~h}$ at $37^{\circ} \mathrm{C}$. The same amounts of fully methylated DNA (Sigma) were also digested as positive controls. The digest reactions were phenol:chloroform extracted and ethanol precipitated. Digested
DNAs were then amplified by PCR using primer pairs MBD3/17, $5^{\prime}$-ACTGGCAGCTCGCAAGGCACA, and MBD3/18, $5^{\prime}$-CGCTGGGAGGAGCCCGTTGAG, which cover 531 bp within the CpG islands in exon 1(see Figure 1). We used Platinum Pfx DNA polymerase (Invitrogen) to amplify the CG-rich region. Each $50 \mu \mathrm{l}$ reaction contained $1 \times$ Pfx buffer, $0.3 \mathrm{M}$ dNTP, $1 \mathrm{~mm} \mathrm{MgSO2,} 0.3 \mu \mathrm{M}$ primers, $5 \times$ PCR enhancer solution and $2.5 \mathrm{U}$ Pfx DNA polymerase. The PCR conditions were $5 \mathrm{~min}$ at $97^{\circ} \mathrm{C}$ as a hot start, then $5 \mathrm{~min}$ at $95^{\circ} \mathrm{C}$ followed by 35 cycles of $\left(30 \mathrm{~s}\right.$ at $95^{\circ} \mathrm{C}, 30 \mathrm{~s}$ at $55^{\circ} \mathrm{C}, 2 \mathrm{~min}$ at $68^{\circ} \mathrm{C}$ ) and finally $5 \mathrm{~min}$ at $68^{\circ} \mathrm{C}$. The PCR products were run on $1 \%$ agarose gels and visualised by ethidium bromide staining.

\section{Mutational analysis by SSCP and sequencing}

PCR of genomic DNA was carried out using six pairs of intron primers as listed in Table 1. These primer sets covered the entire
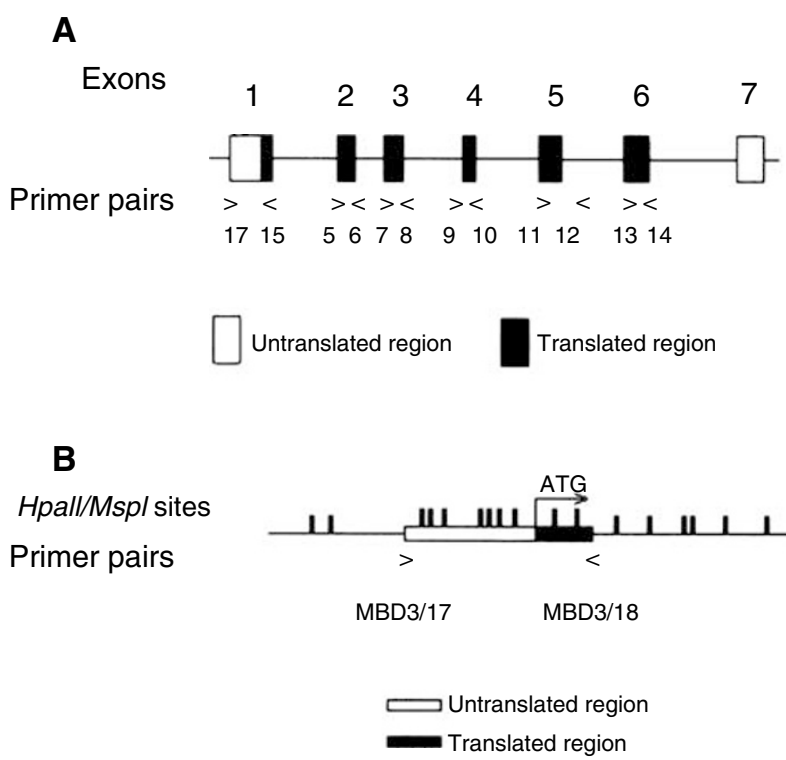

Figure I (A) MBD3 gene structure. (B) MBD3 CpG island Hpall/Mspl restriction sites (CCGG), from Genbank AC005943. 
A
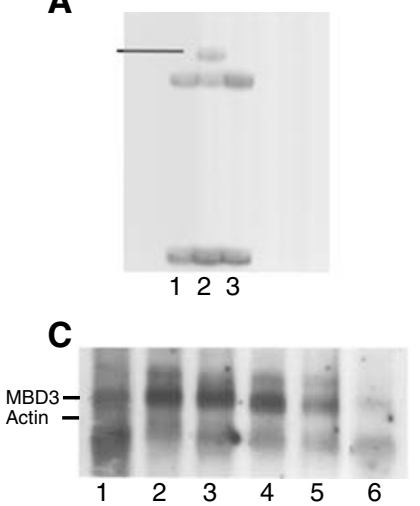

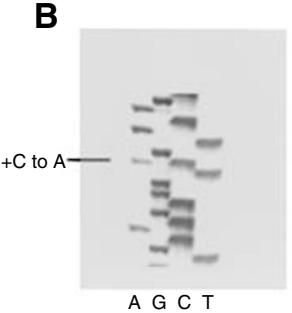

D

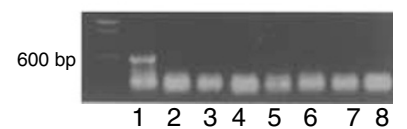

Figure 2 (A) Exon 6 abnormal bandshift on SSCP gel. Cell lines I, 2 and 3 are HCTI 16, DLDI and LOVO, respectively. (B) Heterozygous base change in exon 6 of DLDI. (C) MBD3 polyA + Northern hybridisation. Lanes I-6 are: SW480, COLO320, HCTII6, LOVO, LSI80 and total RNA of the normal colon tissue, respectively. (D) Methylation-sensitive Hpall restriction followed by PCR. Lanes I-9 are: 100 bp marker, methylated positive control, HT29, SW480, Colo320, HCTII6, DLDI, HCTI5 and LOVO, respectively.

coding region (exons 1-6) of $M B D 3$ and included splice acceptor and donor sites (see Figure 1). PCR conditions are included in Table 1 . In all, $1 \mu \mathrm{Ci}$ of ${ }^{33} \mathrm{P}$-dATP (ICN) was added in each $10 \mathrm{ml}$ reaction. PCR products were denatured and run on $0.5 \times$ SequaGel MD gels (National Diagnostics) containing $10 \%$ glycerol and $0.6 \times$ TBE for $18 \mathrm{~h}$ at $6 \mathrm{~W}$ at room temperature. To identify base changes, the PCR products showing aberrantly migrated bands on SSCP gels were sequenced in both strands using the Thermo Sequenase Radiolabelled Terminator Cycle Sequencing Kit (USB) according to the manufacturer's protocol.

\section{RESULTS}

We found three aberrant SSCP bandshifts in 28 cell lines and 51 primary tumour samples, which were then sequenced (Figure 2A, $\mathrm{B})$. All of the changes were heterozygous, as seen by the retention of normal bands in SSCP or sequencing gels, and all were in cell lines. Specifically, in exon 3 of DLD1/HCT15 (cell lines derived from the same tumour), a $\mathrm{G}$ to $\mathrm{A}$ transition in codon 104 coded for a silent change (T104). In exon 6 of DLD1/HCT15, a C to A transversion caused a leucine-to-methionine substitution at residue $248(\mathrm{~L} 248 \mathrm{M})$. In exon 5 of $\mathrm{H} 69$, a $\mathrm{C}$ to A transition was detected encoding a leucine to methionine substitution at residue 161 (L161M). No changes were found in the primary colon tumours. Since matching normal tissues do not exist for the cell lines to confirm somatic mutation events in these cases, we then screened independent normal DNAs to see if these differences exist in cells of noncancerous individuals. The exon 5 variant was found in one out of 47 normals, indicating that it is probably a rare polymorphism, but the exon 6 substitution was not seen in 54 normals, nor the silent exon 3 variant in 47 normals. There is thus a possibility that the $\mathrm{L} 248 \mathrm{M}$ change is a true cancer-related

\section{REFERENCES}

Antequera F, Bird A (1994) Number of CpG islands and genes in human and mouse. Proc Natl Acad Sci USA 90: 11995-11999

Avizienyte E, Roth S, Loukola A, Hemminki A, Lothe RA, Stenwig AE, Fossa SD, Salovaara R, Aaltonen LA (1998) Somatic mutations in LKB1 are rare in sporadic colorectal and testicular tumours. Cancer Res 58: $2087-2090$

mutation, although it is a conservative substitution and so may have little functional effect.

RT - PCR showed that MBD3 expression is detectable in all the cell lines tested (data not shown), an observation confirmed for a selection of the colon cancer cell lines by Northern blot hybridisation of polyA + RNA (Figure 2C), although expression in SW480 relative to $\beta$-actin appears lower than for other cell lines. We went on to test for methylation of the CpG island, but did not find evidence for methylation in any of the colon (including SW480) or lung cell lines (see Figure 2D for colon cancer cell lines, lung cancer cell lines data not shown). The method used to screen for methylation concentrated on the nine HpaII/MspI sites, all of which must be methylated to allow PCR and give a positive result after HpaII digestion, and therefore gives a qualitative (total $v s$ partial/no methylation) rather than quantitative assessment of methylation.

\section{DISCUSSION}

Inactivating $L K B 1 / S T K 11$ germline mutations in combination with loss of the wild-type allele by chromosomal loss or methylation are responsible for the development of hamartomatous polyps and adenocarcinomas in Peutz-Jeghers syndrome patients. LKB1/ $S T K 11$, however, is rarely involved in sporadic colon cancer cases and at most $33 \%$ of NSCLC cases (Sanchez-Cespedes et al, 2002), leading us to consider the role of $M B D 3$ as an alternative tumoursuppressor gene on this location. This gene is tightly linked to LKB1/STK11, being only $500 \mathrm{~kb}$ away on chromosome 19p13.3. To investigate the role of $M B D 3$ in colon and lung tumorigenesis, we assayed for mutations, lack of expression and promoter methylation. We found two missense changes, one out of seven colon cancer cell lines and one out of 20 lung cancer cell lines, and none in colon primaries. Both changes were located outside the MBD, and one appears to be a naturally occurring rare polymorphism. The coincidence of the missense and silent mutations in DLD1/ HCT15 may simply reflect the mismatch repair defect of these cell lines due to MSH6 mutation. RT - PCR amplification and Northern blot hybridisation of the cell lines showed clear expression of the gene, while methylation-sensitive restriction enzyme/PCR analyses showed that none were fully methylated across the region tested. Hypermethylation of other genes involved in tumorigenesis usually shows methylation across the bulk of the associated $\mathrm{CpG}$ island. We would therefore have expected the nine CpG sites we tested of the MBD3 $\mathrm{CpG}$ island (about $50 \%$ of the putative $\mathrm{CpG}$ island for $M B D 3$ ) to have been methylated in a significant proportion of cells to give a detectable PCR result if this phenomenon had occurred. Our expression and methylation results are consistent with a lack of significant aberrant, tumourassociated silencing of the gene. In summary, we conclude that $M B D 3$ is not a major target of genetic or epigenetic alteration in colon and lung cancer.

\section{ACKNOWLEDGEMENTS}

This study was supported by the Cancer Research UK and Chief Scientist Office of the Scottish Executive.
Bader S, Walker M, Hendrich B, Bird A, Bird C, Hooper M, Wyllie A (1999) Somatic frameshift mutations in the MBD4 gene of sporadic colon tumours with mismatch repair deficiency. Oncogene 18: 8044-8047

Dong SM, Kim KM, Kim SY, Shin MS, Na EY, Lee SH, Park WS, Yoo NJ, Jang JJ, Yoon CY, Kim JW, Kim SY, Yang YM, Kim SH, Kim CS, Lee JY (1998) Frequent somatic mutations in serine/threonine kinase 
11/Peutz-Jeghers Syndrome gene in left-sided colon cancer. Cancer Res 58: $3787-3790$

Esteller M, Avizienyte E, Corn PG, Lothe RA, Baylin SB, Aaltonen LA, Herman JG (2000) Epigenetic inactivation of $L K B 1$ in primary tumors associated with the Peutz-Jeghers syndrome. Oncogene 19: $164-168$

Hendrich B, Bird A (1998) Identification and characterization of a family of mammalian methyl-CpG binding proteins. Mol Cell Biol 18: 6538-6547

Hendrich B, Guy J, Ramsahoye B, Wilson VA, Bird A (2001) Closely related proteins $\mathrm{MBD} 2$ and $\mathrm{MBD} 3$ play distinctive but interacting roles in mouse development. Genes Dev 15: $710-723$

Launonen V, Avizienyte E, Loukola A, Laiho P, Salovaara R, Jarvinen H, Mecklin JP, Oku A, Shimane M, Kim HC, Kim JC, Nezu J, Aaltonen LA (2000) No evidence of Peutz - Jeghers syndrome gene LKB1 involvement in left-sided colorectal carcinomas. Cancer Res 60: 546-548

Lukeis R, Irving L, Garson M, Hasthorpe S (1990) Cytogenetics of nonsmall cell lung cancer: analysis of consistent non-random abnormalities. Genes Chromosomes Cancer 2: 116-124

Millar CB, Guy J, Sansom OJ, Selfridge J, MacDougall E, Hendrich B, Keightley PD, Bishop SM, Clarke AR, Bird A (2002) Enhanced CpG mutability and tumorigenesis in MBD4-deficient mice. Science 297: $403-405$

Nan X, Meehan RR, Bird A (1993) Dissection of the methyl-CpG binding domain from the chromosomal protein MeCP2. Nucleic Acids Res 21: $4886-4892$

Resta N, Simone C, Mareni C, Montera M, Gentile M, Susca F, Gristina R, Pozzi S, Bertario L, Bufo P, Carlomagno N, Ingrosso M, Rossini FP, Tenconi R, Guanti G. (1998) STK11 mutations in Peutz-Jeghers syndrome and sporadic colon cancer. Cancer Res 58: 4799-4801
Sanchez-Cespedes M, Ahrendt SA, Piantadosi S, Rosell R, Monzo M, Wu L, Westra WH, Yang SC, Jen J, Sidransky D (2001) Chromosomal alterations in lung adenocarcinoma from smokers and nonsmokers. Cancer Res 61: 1309-1313

Sanchez-Cespedes M, Parrella P, Esteller M, Nomoto S, Trink B, Engles JM, Westra WH, Herman JG, Sidransky D (2002) Inactivation of LKB1/STK11 is a common event in adenocarcinomas of the lung. Cancer Res 62: $3659-3662$

Sansom O, Berger J, Bishop SM, Hendrich B, Bird A, Clarke AR (2003) Deficiency of Mbd2 suppresses intestinal tumorigenesis. Nat Genet 34: $145-147$

Trojan J, Brieger A, Esteller M, Zeuzem S (2000) 5'-CpG island methylation of the LKB1/STK11 promoter and allelic loss at chromosome 19p13.3 in sporadic colorectal cancer. Gut 47: $272-276$

Tycko B (2000) Epigenetic gene silencing in cancer. J Clin Invest 105: $401-407$

Virmani AK, Fong KM, Kodagoda D, McIntire D, Hung J, Tonk V, Minna JD, Gazdar AF (1998) Allelotyping demonstrates common and distinct patterns of chromosomal loss in human lung cancer types. Genes Chromosomes Cancer 21: 308-319

Wade PA, Gegonne A, Jones PL, Ballestar E, Aubry F, Wolffe AP (1999) Mi2 complex couples DNA methylation to chromatin remodelling and histone deacetylation. Nat Genet 23: 62-66

Wade PA, Jones PL, Vermaak D, Wolffe AP (1998) A multiple subunit Mi-2 histone deacetylase from Xenopus laevis cofractionates with an associated Snf2 superfamily ATPase. Curr Biol 8: 843-846

Zhang Y, Ng HH, Erdjument-Bromage H, Tempst P, Bird A, Reinberg D (1999) Analysis of the NuRD subunits reveals a histone deacetylase core complex and a connection with DNA methylation. Genes Dev 13: 1924-1935 